$\triangle C T A$ NEOPHILOLOGICA

DOI: 10.4312/an.48.1-2.67-86

UDK: 82.0-311.9

\title{
The Role of Science Fiction within the Fluidity of Slipstream Literature
}

\author{
Janez Steble
}

\section{Abstract}

The paper explores the complex and contradictory role of science fiction in slipstream, the type of postmodern non-realistic literature situated between the fantastic genres and the mainstream literary fiction. Because of its unstable status of occupying an interstitial position between multiple literary conventions, the article first deals with an expansive terminology affiliated with slipstream and elucidates upon using a unified term for it. Avantpop, transrealism, and interstitial fiction all help us in understanding the vast postmodern horizon of slipstream. Furthermore, the slipstream's philosophy of cognitive dissonance in comparison to science fiction's is analysed to see the similarities and differences between them. The section is mainly concerned on expanding Darko Suvin's concept of cognition and viewing it as partially compatible with slipstream's estrangement techniques. The final part is focused on the exemplary slipstream novel Vurt by Jeff Noon, a perfect example of science fiction providing material, including latest post-Newtonian paradigms of science, for slipstream to mould it in its own fashion.

Key words: slipstream, science fiction, Avant-pop, transrealism, interstitial fiction, cognitive dissonance, chaos theory 


\section{INTRODUCTION}

William Wordsworth in his preface to Lyrical Ballads (qtd. in Brigg, 3) already foresaw the need for literature ${ }^{1}$ to expand its subject matter to that of science and technology. He claims the latter phenomena will be "familiarized to men" and become "the household of man", and that the "poet " will be present to not only perceive the transfigured world, but be an active participant in its transfiguration. In the 20th century, especially the post-WWII period, this commingling of the world of science and literature has become commonplace, not just because of the specific genre of science fiction, but mainly because mainstream, and even canonical, authors have seen the need to "embrace the precepts and influence of science and engender a vision of man that takes account of our science-laden times in both style and subject matter" (Brigg 2002, 5). However, when it comes to the stories of the late 20th century and now of the new millennium another Romantic poet can shed some light upon the particular trend of the latest fiction, namely John Keats and his concept of negative capability: “... that is when man is capable of being in uncertainties, Mysteries, doubts, without any irritable reaching after fact and reason" (qtd. in Wolfe 2002, 185). Joining Wordsworth's speculation on the never-ending horizon of science and Keats's epistemology of uncertainties is not at all impossible and ludicrous. The two views can easily complement each other and the best form of literature to attest to that is slipstream, the elusive and slippery mode of writing which is essentially the continuation of postmodernist fiction via unprecedented degree of genre miscegenation. The immediate inherent problem of dealing with slipstream fiction is its interstitial and liminal position between different, and even contradictory, themes and genres it employs - it is not out of the ordinary to read a slipstream story fusing both the realist and fantasy narrative frameworks without coming apart at the seams.

The proliferation of science, technology and information has rendered our postmodern world in epistemological and ontological crises. Even though authors have no choice but to follow the speculation of Wordsworth, they also find the domesticity of realism and the rigorousness of science fiction inadequate when trying to hold the mirror up to everyday life. ${ }^{2}$ Genre miscegenation implies the fusion of the following narratives: science fiction, fantasy, horror, detective story, magical realism and realistic modes (writers operating within genre territories

1 Specifically, he was referring to poetry, yet the general tone of his address implies the universal meaning of the preface. See Peter Brigg's The Span of Mainstream and Science Fiction: A Critical Study of a New Literary Genre.

2 Brian McHale claims for postmodernist fiction that it imitates "the pluralistic and anarchistic ontological landscape of advanced industrial cultures" $(2003,38)$. The same holds true for slipstream narratives which emphasize this problem of imitation by employing tropes from every available genre. 
would call the latter mainstream). My aim in the article is to delineate the complex role played by the genre of science fiction in this interstitial and fragmented mode of writing called slipstream. Due to the exhausting nature of dealing with various genres in such a multifarious type of literature, I will have to limit myself to one. The point of this delineation is to show that science fiction within such literature can resume its dialectical relationship between cognition and estrangement, albeit sometimes estrangement alone taking the dominant role in this relationship. It can be argued that slipstream is not only the continuation of postmodernist fiction, but specifically the continuation of science fiction due to the simple fact that both fictional modes steadfastly interrogate the mutable worlds of human experience. In the end, Keats's negative capability essentially sets the tone for how science fiction acts in the non-realistic mode of slipstream.

\section{PROFUSION OF TERMS}

\subsection{Settling for the Name}

The definitions, terms, and descriptions following the discourse of slipstream are anything but exact and systematic. Ever since Bruce Sterling came up with the name ${ }^{3}$ in 1989 the discussions surrounding slipstream have been increasingly proliferating and contradictory. Slipstream is not even a common name given to the ever-increasing ascendancy of interstitial literature of the 21st century. Gary K. Wolfe and Amelia Beamer have simply found it necessary to call this literature $21^{\text {st }}$ century stories, ${ }^{4}$ a makeshift name for works which are otherwise dispersed into a "panoply of new terms": slipstream, interstitial. Transrealism, New Weird, nonrealist fiction, New Wave Fabulist, postmodern fantasy, Postgenre fiction, cross-genre, span fiction, Artists without Borders, New Humanist, Fantastika, liminal fantasy (Wolfe 2011, 164). In this section I will add a few more to this terminological menagerie. Using the specific term "slipstream" among such a treasure trove of signifiers is thus problematic in itself and warrants an explanation. With so many recently published anthologies of slipstream/postmodern fiction, especially under the editorship of James Patrick Kelly and John Kessel, one, whether a reader or a critic, is bombarded with almost as many concepts as there are stories. The decision of using one term over another can lead to the exclusion of one anthology over another. Due to the specific nature of this article, I have the privilege of using one term, namely "slipstream", among many, which is the term

3 The essay originally appeared in SF Eye 5 (July 1989): 77-80.

$4 \quad$ Some of the authors commonly referred to as writers of slipstream were prolific in the late $80 \mathrm{~s}$ and $90 \mathrm{~s}$ of the 20th century. This means that slipstream is so elusive we cannot even pinpoint it to one decade. 
most commonly tied with some of the science fiction narratives in the late 20th and early 21st centuries. ${ }^{5}$ My aim is not to provide a new definition, to explain and to describe all of the terms associated with naming these $21^{\text {st }}$ century stories or to even attempt to concretize the fluid nature of such fiction, but mainly to expose and critically evaluate the philosophical standpoints of this profusion and confusion of terms and definitions.

For my purposes Peter Brigg's use of span fiction actually comes close to how I deal with the role of science fiction in slipstream. Span fiction, as the name implies, connects the realms of mainstream and science fiction, it connects "two land masses" (Brigg 2002, 14). Authors, officially subsumed under another fluid, yet commonly known term postmodernist fiction, are his main examples: "Pynchon's span fiction is about people in a world surrounded by the physical presence of science (technology) and holding a worldview frequently expressed in the language or metaphors of science" (72). This is useful for grasping the underlying philosophy of a plethora of authors ranging from the period of New Wave science fiction to the interstitial fiction of the 21st century, and therein lies the problem. Span fiction becomes too widespread all too quickly, throwing authors from Samuel R. Delany, Ursula K. Le Guin, J. G. Ballard to Thomas Pynchon, Doris Lessing, Don DeLillo in one conceptual basket. These umbrella terms, encompassing too many authors and too many periods, are all too frequent in such discourses. If one takes into account the prolific and experimental period of the New Wave science fiction, there is no need to come up with a new term in the first place - science fiction can be span fiction by default. However, there are two reasons why I will not resort to using span fiction as the unifying name for the prose I am analysing here, namely the concept of genre and the frequency of usage. A genre implies a common set of reading, writing and marketing/publishing conventions. As a philosophical category, the genre of span fiction can be of some use, especially if we find common traits in given authors, but genre in literary criticism should also encompass marketing/publishing strategies, and readers' conventions, and even fandom. Science fiction as a genre exists in literary form and style with its own unique history and development, it exists as a collection of books on a shelf in a store, it exists as a set of reading/interpretation practices, and it exists as a marketing category spanning multiple media. Span fiction is a coinage by Peter Brigg and it essentially exists solely as a philosophical category, and thus a new issue emerges - the frequency of usage is too rare to have any meaningful echo beyond his critical study. It cannot be called a real genre per se and one rarely encounters the term in slipstream studies. Brigg's study and even terminology is very useful

5 Since New Weird is directly connected with horror and New Wave Fabulism with fantasy I can to some degree forego the narratives associated with these "genres". 
and illuminating, but because he tries to literally come up with a new genre, it becomes too ambitious.

Unfortunately, "slipstream" is just as problematic in this regard as "span fiction”. In fact, Brigg emphasizes Sterling's original article, namely how the name "slipstream" is temporary and subject to scrutiny and eventual change by future critics, and how John Clute in his The Encyclopedia of Science Fiction (1993) deems it unsatisfactory. ${ }^{6}$ However, James Patrick Kelly and John Kessel in the introduction to their slipstream anthology Feeling Very Strange update the term by emphasizing the denial of its status as a bona fide genre and underlining the effect this type of literature produces, thus avoiding the contentions inherent in genre creation/naming, ${ }^{7}$ and in this article I am mainly resorting to their non-rigorous and descriptive usage of slipstream as "the literature of cognitive dissonance ${ }^{8}$ and of strangeness triumphant" (xi). In other words, slipstream is not a genre, ${ }^{9}$ but a literary effect. Even back in 1989 Bruce Sterling did not dare call slipstream a full-blown genre - it is pertinent to quote him verbatim on the subject:

This genre is not category SF; it is not even "genre" SF. Instead, it is a contemporary kind of writing which has set its face against consensus reality. It is fantastic, surreal sometimes, speculative on occasion, but not rigorously so. It does not aim to provoke a "sense of wonder" or to systematically extrapolate in the manner of classic science fiction.

Instead, this is a kind of writing which simply makes you feel very strange; the way that living in the late twentieth century makes you feel, if you are a person of a certain sensibility. We could call this kind of fiction Novels of a Postmodern Sensibility ... for the sake of convenience and argument, we will call these books "slipstream". (qtd. in Kelly, J. P. and Kessel, J. 2006, viii)

In this revealing passage we find descriptions rather than any forms of definition. Indeed, the whole of Sterling's article is littered with complex terminology from literary criticism and postmodernist discourse, yet at the same time he

6 "The image is either nautical or aeronautical: a ship or an airplane (either of which stands for genre $\mathrm{SF}$ ) can create a slipstream which may be strong enough to give non-paying passengers (PaulTHEROUX, say) a ride. As a description of commercial piggybacking, the term seems apt; however, when used to designate the whole range of non-genre SF here called FABULATION, the term - which implies a relationship of dependency - can seem derogatory" (qtd. in Brigg 2002, 12).

7 "Science Fiction has not been well served by its seventy-year-long war of definition, and moreover, what right do we have to raise the walls of a new genre around writers who have no commitment to or even knowledge of what we think of as slipstream?” (Kelly, J. P. and Kessel, J. 2006, x-xi)

8 More on this concept in the next section.

9 The editors at one point do actually suggest that slipstream "might well be the beginnings of genre" (xi). 
rightly avoids any rigorousness that we may find in Darko Suvin, ${ }^{10}$ for example. From the very inception of the term, we thus have a healthy and non-restrictive manoeuvrable discourse in which we can analyse the fluid and cross-generic literature of modern times.

But what of the name slipstream itself? Kelly and Kessel quickly make us aware of Sterling's implications. ${ }^{11}$ Many of the authors Sterling provides as outstanding examples of slipstream are not part of any genre at all, and the article was largely directed to the audience of genre literature. If there is slipstream, then there is mainstream, and the connection between the two is intrinsic. If we take a look at the dictionary definitions of slipstream, the primary meanings relate to aerodynamics, hence the whole conception is analogy-based. In the succinct definition "a stream of air behind any moving object" replacing "stream" with a slipstream story and "any moving object" with the literary development of either genre fiction or mainstream gives us a sufficient conception of slipstream. These stories are behind or moving in the margins of either the flow of genre(s) or the mainstream world of literature. They are fluid in nature because they partake in multiple genre conventions and are part of the wake, the trail or the margins of conventional literature. Their ambivalent ontological status perfectly reflects the world(s) they are imitating, marking an even greater departure from the outlook of modernism - "The modernist mindset is alienation. You're looking at Henry Ford's machine system, and you can't deal with it, and you want to retreat to some interior creative space. But in a postmodern stance you are so infiltrated by the various shattering aspects of the postmodern condition that your own core identity fragments. You become a kind of multi-tasking personality ...” (Sterling 2011, 9). In slipstream this multi-tasking is specifically achieved by "the careful modulation of postmodern, genre, and traditional literary elements, all undermining each other, all augmenting one another, but without quite resolving into the authority of any single mode" (qtd. in Wolfe 2011, 19). What is most important here is the emphasis on the unresolved nature of slipstream - we are dealing with a multi-tasking literature, but without any "task" or mode being finished in the process. Fluidity, interstitiality, fragmentation, modulation - all of these descriptive markers are subsumed in the central term "slipstream" I am using in this article. It is by no means a perfect term, but merely adequate, and its best feature is the ongoing discourse it has been brewing since Sterling's conception of it. Like science fiction, it has become a discursive field.

In the special issue on slipstream in vol. 38 of Science Fiction Studies there is an abundance of explanations and heated debates either confirming and improving

10 Suvin's border policing will play a major role in the next section.

11 "From the outset, Sterling defined slipstream as largely a mutant form of the mainstream" (viii). 
Sterling's controversial term or simply trying to negate it altogether, but there is no doubt that there is a consensus among most of the writers, readers, and critics in using "slipstream" as the common signifier for the fragmented and multi-generic fiction the world of literature has been facing since the dawn of postmodernism. ${ }^{12}$ Authors in this special issue of the journal repeatedly emphasize how this "genre", when compared to science fiction, faces a special conundrum: "Trying to get slipstream writers together is like herding cats. I don't think they have a temperament with which they can unite" (Sterling 2011,6). There are as many conflicting interests between the authors of this fiction as there are novels associated with these interests. Some may plunge into the occult of Lovecraftian horror ${ }^{13}$ others into the fractal narratives expressing the nonlinear dynamics of chaos theory. ${ }^{14}$ Furthermore, without social phenomena, such as science fiction fandom, fanzines, and criticism, it is difficult finding a common group of people writing these stories or narrative methods. No bookstore has a special label "slipstream" with which a reader is guided through certain bookshelf mazes; in fact, it is quite common to find various slipstream novels overlapping different, and even conflicting, genres. ${ }^{15}$ There are, of course, no resolutions found in these studies, and that is precisely the point - the discursive field is open, growing in size each time a new work of fiction tries to pursue the fluid ontological waters of slipstream.

The most illuminating concept pertaining to slipstream activity as a whole that I have come across in these studies is found in Justin St. Clair's article on Pynchon's Against the Day, namely bricolage. This is another observation that stems directly from Sterling's thoughts, and it is again relevant to quote him verbatim:

Slipstream is also marked by a cavalier attitude toward "material" which is the polar opposite of the hard-SF writer's "respect for scientific fact". Frequently, historical figures are used in slipstream fiction in ways which outrageously violate the historical record. History, journalism, official statements, advertising copy ... all of these are grist for the slipstream mill, and are disrespectfully treated not as "real-life facts" but as "stuff", raw material for collage work. Slipstream tends, not to "create" new worlds, but to quote them, chop them up out of the context, and turn them against themselves (emphasis in original). (qtd. in St. Clair 2011, 46)

12 The afore-mentioned Kelly and Kessel based their selection of slipstream stories on authors "active today, primarily in the period since Sterling's essay" (xiv).

13 The New Weird of China Miéville, if we take a famous example in this growing trend of horror.

14 Jeff Noon's Vurt is a perfect testament to that.

15 Pawel Frelik ascribes this overlapping status to slipstream in general: "In Miéville's The City and the City Beszel and U1 Qoma largely occupy the same physical space. How this is exactly possible is never explained, which makes the novel an emblematic Slipstream text - such ontological conundrums are central to many S-stories" (Frelik 2009). 
Bricolage as creation/construction of something from divergent sources that are given in the detritus of the world directly connects slipstream with the postmodern modes of thought, found in Derrida and Deleuze/Guattari, to name a few. The former attributed this fiddling/tinkering activity to discourse in general, ${ }^{16}$ and the latter two described it as the characteristic mode of production of the schizophrenic producer (Deleuze, G. and Guattari F. 2004, 7-8). As was stated previously when referring to the postmodern stance of slipstream, this "schizophrenic producer" is precisely the multi-tasking man tinkering with either the pop-cultural items strewn across the urban landscapes or the post-generic texts and samples scattered throughout the media. The bricoleurs of slipstream are not usually associated with communities of fandom and agendas, found in science fiction. The source material for their works comes from the never-ending chain of signifiers, the signified being lost in the sea of genres spanning at least two centuries of literature. Bricolage is thus another item to add to the ever-growing list of slipstream descriptive markers. With so many concepts and ideas attributed to and subsumed in the term slipstream it is more than enough to warrant using it as a common name when traversing this nonrealistic "genre" of postmodern sensibility.

\subsection{Other Helpful Terms}

Before venturing into the methods and philosophy of slipstream as a literary effect, it is prudent to outline some additional terms we inevitably encounter when critically approaching this kind of fiction. The common thread behind this terminological morass is the intrinsic connection between slipstream and science fiction. Settling for the name, as has been mentioned, is just one part of the problem, the other being finding linking concepts and notions that help us understand slipstream as the continuation of science fiction and science fiction as playing a central or marginal role in slipstream narratives, depending on the authors intention, the critique, or readers' reception. Pinpointing the degree of science fiction qualities, such as the style and tropes, featuring in mainstream postmodernist works in the 60s and 70s of the 20th century, is an arduous task in itself; however, since the appearance of Sterling's article the situation has only exacerbated - the proliferation of fiction eluding the critical edifice established in the late decades of the 20th century is reaching an overload to the degree that the notion of genre itself is being supplanted ${ }^{17}$. My goal here is not to augment the critical frustration

16 See "Structure, Sign, and Play in the Discourse of the Human Sciences". Available online: http:// hydra.humanities.uci.edu/derrida/sign-play.html

17 See Gary K. Wolfe's Evaporating Genres - Essays on Fantastic Literature. 
when faced with this liquid realm of post-generic fiction, but to, on the contrary, expose the vigour, or at least flexibility, that slipstream can bestow upon science fiction. ${ }^{18}$

Robert Scholes' tongue-twisting "structural fabulation", coined in 1975, is an attempt to implement structuralism into certain science fictional narratives displaying greater artistry towards humanistic concerns than their pulp-oriented counterparts. Specifically, works of Daniel Keyes, Olaf Stapledon, Frank Herbert, John Brunner, and Ursula K. Le Guin are at the forefront here. He further develops the notion of cognitive estrangement and, continuing Viktor Shklovsky's line of thought on estrangement/defamiliarization, emphasizes how science fiction uses a different approach in achieving ostranenie - the focus in science fiction is more on the conceptual side rather than verbal. His purpose was to essentially dispel certain misconceptions surrounding the then conservative criticism and to expose science fiction works of great quality, such as Keyes' Flowers for Algernon, and Le Guin's The Left Hand of Darkness, to the wider audience. By constructing a new name for science fiction he tried to uplift the critical status of the genre as a whole.

In works of structural fabulation the tradition of speculative fiction is modified by an awareness of the nature of the universe as a system of systems, a structure of structures, and the insights of the past century of science are accepted as fictional points of departure. Yet structural fabulation is neither scientific in its methods nor a substitute for actual science. It is a fictional exploration of human situations made perceptible by the implications of recent science. Its favorite themes involve the impact of developments or revelations derived from the human or the physical sciences upon the people who must live with those revelations or developments. (Scholes 1975, 42)

What is most revealing here is how this elaboration connects to the afore-mentioned Briggss span fiction when dealing with authors, e.g. Thomas Pynchon and Doris Lessing, who are much less directly affiliated with the science fiction genre than, say, Daniel Keyes. The line of reasoning again echoes Wordsworth's proclamation of science as the subject matter of future art. Scholes felt the need to expose the mature perspective on human existence amidst the flexible landscapes of science and technology that certain science fiction works display, and further critics, such as Brigg, felt the same way when it comes to post-WWII mainstream literature in general. Science fiction's constant exploration of the relationship between the human landscapes and human experiences thus eventually leads the genre not just towards the employment of "soft sciences" and humanities, but also

18 "... the entire history of slipstream with its discontents could perhaps be viewed not as an emergence and formative pains of a new literary entity but a symptom of sf s vibrancy and creativity" (Frelik 2009). 
towards cross-generic and interstitial trends witnessed in slipstream. Structural fabulation with its emphasis on radical discontinuity with the empirically given world is, in effect, an insightful precursory remark on slipstream literature.

Just as the theories of structural fabulation and span fiction herald the effacement of the dividing line between human everyday perception and scientific reality, Avant-pop of the $90 \mathrm{~s}$ in the $20^{\text {th }}$ century tried to accomplish the same annulment between the ubiquitous horizon of pop culture and sophisticated art. In other words, Avant-pop is a tendency toward "deconstructing the difference between high art and junk culture" (Tatsumi 2006, 30). Similar to slipstream, Avant-pop is one among a plethora of post-postmodernist literary endeavours to try to make sense of the onslaught of contradictory perceptions we are faced with in the late-capitalist world. Since it is a fusion of two extremes, namely "the avant-garde's impulse to push the aesthetic envelope, embodied in disorienting time/reality shifts, and the addiction to pop culture exemplified by an exploration of various aspects of pop Americana from McDonald's to soap opera, including the ransacking of sf themes"19 (Rossi 2002, 20), it is not surprising to see many writers who belong to science fiction, Avant-pop, and slipstream at the same time. The pastiche approach to sci-fi genre hybridizing and thematic appropriation makes the separation between slipstream and Avant-pop all the more difficult. Jonathan Lethem and Jeff Noon, for example, are simply authors belonging to both "camps". As it is with all slipstream fiction, everything depends on the modulation and reception. ${ }^{20}$ Avant-pop assists us in understanding slipstream due to its insistence on accepting the pop cultural detritus, littered with science and technology, as the new human clay with which we can actively construct ourselves, reality, and perceptions. ${ }^{21}$

Transrealism is another literary endeavour facing perceptions, another form of literature that sets its face against consensus reality, as Sterling would say. It “... conveys an enlivening approach to realistic fiction that enhances the vividness of its characters and events by imbuing them with elements drawn from fantastical imagination" (Broderick 2009,52). The originator of the term Rudy Rucker wrote the manifesto ${ }^{22}$ in a similar fashion as Mark Amerika with his own proclamation of avant-gardism:

19 This specifically refers to Jonathan Lethem's exemplary Avant-pop novel Amnesia, which bears universal merit.

20 If we take the example of Jeff Noon's Vurt, the Avant-pop reception of it would focus more on the mass media elements and informational distribution featured in the hectic plot.

21 "The emerging wave of Avant-Pop artists now arriving on the scene find themselves caught in this struggle to rapidly transform our sick, commodity-infested workaday culture into a more sensual, trippy, exotic and networked Avant-Pop experience" (Amerika 1993).

Available online: http://www.rudyrucker.com/pdf/transrealistmanifesto.pdf 
Transrealism is not so much a type of SF as it is a type of avant-garde literature. I feel that Transrealism is the only valid approach to literature at this point in history. The Transrealist writes about immediate perceptions in a fantastic way. Any literature which is not about actual reality is weak and enervated. But the genre of straight realism is all burnt out. Who needs more straight novels? The tools of fantasy and SF offer a means to thicken and intensify realistic fiction. By using fantastic devices it is actually possible to manipulate subtext. The familiar tools of SF - time travel, antigravity, alternate worlds, telepathy, etc. - are in fact symbolic of archetypal modes of perception. (Rucker 1999)

Immediate perception and the immediate surrounding world are again in the foreground, mimesis being the main method with which an author grasps the world and thus resuming the ontological preoccupations of postmodernist fiction in toto. The character of a transrealist novel is usually the author, narrating the world as he/she faces it with the help of science fiction tools. The main format of transrealist fiction are thus semi-autobiographies: Rudy Rucker's White Light (1980) and Jonathan Lethem's The Fortress of Solitude (2003), for example. Transrealist method is essentially transgressive realism - the consensus reality is the subject matter, yet one has to transgress the conventions of mainstream/realist fiction by shunning its framework, to transcend it. It does not come as a surprise that Philip K. Dick ${ }^{23}$ is the precursor to this trend - the novel VALIS (1978), featuring Dick/Horselover Fat as a character split between two personalities and in which he constantly interjects the plot with metafictional sly remarks, can be considered as the prototypical transrealist fiction. It is also worth mentioning here that his mainstram/realist novels never truly worked and became as successful as his science fiction ones because he always found tame empirical reality insufficient to describe what he felt and perceived. In fact, Dick's necessary venture into science fiction, and how science fiction functions in transrealism, can explain an important role science fiction plays in splistream - it is there to better explain the subjective and objective world(s).

Last, but not least, interstitiality is an important concept regarding the special position slipstream occupies in the multi-genre space. As with Avant-pop and transrealism, interstitial fiction is a recent trend with its own "manifesto" 24 and two anthologies. ${ }^{25}$ There are two main focuses here that need to be addressed. "Interstital works maintain a consciousness of the boundaries they have crossed or disengaged with; they present a clear awareness of the kinds of subtexts which might

23 One of the most influential authors of postmodern literature of every possible subset.

24 An introduction to the Interstitial Arts Foundation can be found online: http://www.interstitialarts.org/what/intro_toIA.html 
be their closest classifiable counterparts" (Fenkl, H. I. 2007, iv). This fiction is not actually liminal, it is not trying to become something else, but rather literally stays in the interstices and thus maintains a unique epistemological and ontological position. It is its own non-category. The in-between position is referred to as the DMZ (de-militarized zone):

Interstitial works are self-negating. That is, if they become successful to the degree that they engender imitations or tributes to themselves, or if they spark a movement which results in like-minded works, then they are no longer truly interstitial, having spawned their own genre, subgenre, or even form. The DMZ they initially inhabit becomes its own nation, so to speak. (v)

Both anthologies accentuate the strength of this fiction due to its precarious position - vitality and innovation stemming from marginality. Secondly, the genre indeterminacy provides a special relationship to reception: "What the Interstitial does, actually, is transform the reader's experience of reading. Formerly invisible historical trajectories become visible to the reader (vi)". Again we come full circle - interstitial fiction as the enlivenment of experience, the crystallization of perception. ${ }^{26}$ As the short stories in the anthologies attest, interstitial fiction holds no hesitation to turn to science fiction, fantasy, horror, magical realism, and many other genres/categories to defamiliarize readers' given reality to the nth degree.

\section{COGNITIVE ESTRANGEMENT AND COGNITIVE DISSONANCE}

As much as the definitions and explanations concerning science fiction try to move away or beyond Suvin's staple definition, it is nevertheless necessary to return to it, especially for the purpose of extracting the genre's core from the slipstream flow. The main controversial feature of his approach is first, and foremost, in the exclusive nature of the prescription: "Suvin's despotic denial of the sf label to a wide range of texts exemplifies the politics of purity inherent in border policing" (Frelik 2011, 23). The author denounces Suvin's labeling of Ray Bradbury as a "science-fantasy" writer, because he not only excludes him from science fiction in general, but reduces everything that is not exactly science fiction to impurity. The denouncement is, of course, perfectly justified, and it is ironic that here we are using Suvin to help us understand slipstream, because Frelik's point is that

26 If there is a difference between transrealism and interstitial fiction, it would again have to be in the direction of the narrative focus. Interstitial fiction tries to break the rules a reader deems unbreakable, ergo much more focus is put on establishing genre conventions only to break them apart when the reader least expects it. 
writers like Bradbury testify that "from the moment of its naming sf has always had its slipstream - a steady line of texts that failed to contain themselves within the envisioned borders of the genre" (23-24). If we actually delve into the concept of cognitive estrangement, things are not as bleak and exclusive as they seem. The point is to consider it as a guide through the various estrangement techniques slipstream likes to employ, not as a prescription one should follow to the letter. The role of science fiction as cognitive estrangement need not be fully oppositional to the role of slipstream as cognitive dissonance, especially considering the flexibility of cognition.

To briefly reiterate Suvin's definition: " $S F$ is, then, a literary genre whose necessary and sufficient conditions are the presence and interaction of estrangement and cognition, and whose main formal device is an imaginative framework alternative to the author's empirical environment" (Suvin 1979, 7-8). Estrangement is mainly derived from Bertolt Brecht's distancing/estrangement effect used in theatre to provoke the audience into critical thinking concerning their immediate perception of the play. Breaking the fourth wall definitely counts as one of the main methods in achieving the estranging effect, in postmodern literature the device is called metafiction. Kessel and Kelly in their introduction to their famous slipstream anthology posit metafictional games as one of the techniques to estrange us. ${ }^{27}$ In a reductive and simplified sense, estrangement differentiates science fiction and other fantastic genres from the realistic/mainstream mode. Suvin, of course, wishes to specify the estrangement by emphasizing Brecht's thoughts on Galileo and his detached observation of the swinging chandelier: "... He was amazed by that pendulum motion as if he had not expected it and could not understand its occurring, and this enabled him to come at the rules by which it was governed" (qtd. in Suvin, 6). The type of estrangement described here is cognitive and creative, or, if we use Scholes' wording - the focus on "rules" makes the estrangement conceptual rather than verbal.

Cognition and the presence of a novum ${ }^{28}$, is, then, the specifica differentia of science fiction by which Suvin tries to exclude fantasy, myth, folk-tale, science-fantasy, and other "non-cognitive" genres. However, the concept of cognition is much wider than science ${ }^{29}$ or the employment of technological gadgetry: "Significant modern SF, with deeper and more lasting sources of enjoyment, also presupposes more complex wider cognitions: it discusses primarily the political, psychological, and anthropological use and effect of knowledge, of philosophy of science, and the

27 They refer to the short story "The Rose in Twelve Petals" by Theodora Goss.

28 "SF is distinguished by the narrative dominance or hegemony of a fictional 'novum' (novelty, innovation) validated by cognitive logic" (63).

29 Suvin warns us that the Anglo-Saxon meaning of "science" is too restrictive in the first place (13). 
becoming of failure of new realities as result of it" (15). New Wave science fiction, if we take the science fiction trend which does not involve "hard sciences", with its attention to psychology, politics, sexuality, and religious issues definitely fits the prescribed cognitive role. Mathematical sciences and humanities are all subsumed under "cognition". Following cognition is the presence of some sort of a novum - a device, gadget, novelty, idea, character, space, society, etc. - estrangement and cognition thus revolve around this novum and build the narrative logical to it. The novum is in science fiction usually foregrounded and is the novelty that directly estranges the readers like a focused lens. If we take the extreme case from the New Wave science fiction anthology Dangerous Visions (1967), "If All Men Were Brothers, Would You Let One Marry Your Sister?" by Theodore Sturgeon, the novum is the society based on the idea - driving the Freudian thought on the repression of incestuous desires to its unintended conclusion - that free practice of incest makes the society happier and healthier. The novum, specifically based upon Freudian psychoanalysis, makes us not only become estranged, but lets us critically question the status quo of "normal" society. If we take into account the multitude of modern slipstream stories we can find a plethora of nova estranging the readers in various ways; however, as soon as we explore the nature of these nova, we find ourselves at odds with Suvin's persistence on validation by cognitive logic and philosophy of science, i.e. the supposed specifica differentia of science fiction. Sturgeon's New Wave science fiction story is one thing, but Ted Chiang's slipstream story "Hell is the Absence of God" (2001) with the novum being the literal existence of Heaven and Hell in the modern world, is quite another. The latter story is excluded from science fiction on the grounds of cognition, at least as it is formulated by Suvin, in the same way as Ray Bradbdury's The Martian Chronicle (1950). However, both contain a novum and the estrangement effect. Do we require a new category here or the expansion of the existing one?

The category of cognition enters a whole new dimension when subjected to slipstream interrogations. To reiterate, slipstream is the literature of cognitive dissonance - holding two or more contradictory views simultaneously, cognition here can take the form of a belief, perception or idea. In Suvin's terminology cognition in science fiction leads to the resolution of contradictions, in slipstream one form of cognition leads to a wave of conflicting ones with no resolution in sight. In fact, slipstream prides itself on being schizophrenic: "We contend that slipstream is an expression of the zeitgeist: it embraces cognitive dissonance rather than trying to reduce it" (Kelly and Kessel, xii). Questions, such as "how long can you stand to both love and hate an abusive father?", "if you believed destroying weapons of mass destruction justified the invasion of Iraq, how do you feel about the war now?", or even "if God created everything, then who created God?" all fall under the domain of slipstream. They all contain within themselves a certain 
form of cognition, whether it is of purely pathological or intellectual nature. If these questions are posed as a slipstream narrative, then they also surely contain a novum which is the basis for the plot, and, of course, there can be no doubt the novum will tend to estrange. These specific questions are incompatible with the cognition Suvin prescribes to the definition of science fiction; however, Kessel and Kelly also pose another question taken directly from the scientific circles: "Is an electron a wave or a particle?" Slipstream answers “yes" on both accounts.

The dual/contradictory nature of sub-atomic particles has been well documented in quantum mechanics. Coupled with the onset of chaos theory ${ }^{30}$ and fractal mathematics the Newtonian/Cartesian reality that we take for granted all of a sudden falls apart and contradiction becomes part and parcel of the very fabric of our universe. Sub-atomic particles become as unstable as our postmodern identity, one flap of a butterfly's wings leads to a hurricane at the other end of the world, one tiny change in our daily routine causes a nervous breakdown - the world of science and the world of man joined once again in all of their glorious contradictions. Should not chaos theory and quantum mechanics fall under "cognitive logic"? It is, after all, a recognized branch of theoretical and applied sciences, and, as quantum mechanics is the continuation of Newtonian mechanics, so can slipstream be the continuation of science fiction. As has been stated, both cognitive estrangement and cognitive dissonance, when applied to fictional narratives, are based upon the trio of novum, estrangement, and cognition. If Suvin's approach to defining science fiction's cognitive logic is extended towards the latest trends of science, ${ }^{31}$ then even one of the most rigorous approaches to science fiction theory can include the fluidity of slipstream fiction. However, as interstitial fiction demonstrates, as soon as we find ourselves in a comfortable spot of cognitive validation, i.e. as soon as the narrative assumes the mantle of science fiction genre, we are quickly transported into another realm with its own rules or even a complete lack of rules. One moment we are in the zone of Fordist mechanical reproduction, next we step into the world of Heisenbergian indeterminacy, and finally enter the land of unicorns and faeries, etc. The science fiction framework may be able to help us understand the rules of two of those worlds, not all, and we simply have to accept the fact that in this type of fiction lack of total understanding is its virtue and raison d'être. The role of science fiction within slipstream becomes a contradiction in and of itself - its strongest feature becomes its greatest weakness.

30 This will be briefly touched upon in the next section discussing Noon's narrative of Vurt.

31 It is worth mentioning here Steven Hall's debut novel The Raw Shark Texts (2007), a slipstream narrative taking its cue from the latest developments in database research, including the all-pervasive internet. See more on this subject: N. Katherine Hayles' Material Entanglements: Steven Hall's The Raw Shark Texts as Slipstream Novel in Science Fiction Studies 38, no. 1 (March 2011): 115-133. 


\section{THE STRANGE CASE OF VURT}

Finding slipstream novels and short stories, which represent the continuation of science fiction and at least to some degree employ the dialectic of cognitive estrangement, among a plethora of diverse authors, interests, and genre markers becomes all the more difficult when certain critics, publishers or editors come up with new names, anthologies, and publishing labels on a yearly basis. ${ }^{32}$ The example we will shortly touch upon here is but a stepping stone and is by no means exhaustive. The field of slipstream is so diverse and open the process of selection and exclusion, even when it comes to a specific genre, is always subject to change. After all, we never step into the same slipstream twice. Slipstream is a prolific territory for writers of varied interests and talents to tackle genres they are not even part of or simply do not find them satisfactory. In effect, readers are facing a similar problem: "Science fiction has been undergoing a kind of crisis of confidence. Some have worried that our stories are too often pitched at that narrowest of science fiction audiences, those who have spent lifetimes reading the stuff. The world building had gotten so complex that readers who are new to the genre get confused, then frustrated and many give up. There has been a call for a more accessible science fiction, which still maintains the virtues of the genre" (Kelly, J. P. 2009, 278). Therefore, science fiction via slipstream rears its head again to resume its ongoing mission of estranging us and boldly opening up new vistas for readers and writers alike.

Jeff Noon's debut novel Vurt (1993) is a helter-skelter narrative of fractal dimensions ${ }^{33}$ set in an alternate version of Manchester with futuristic characteristics we can find in typical science fiction novels, such as cyborgs, telepaths, mutants and virtual realities. We follow Scribbler and his motley crew of Stash Riders in search for his sister through the drug-induced cyberpunk-like environments of Vurt - the unified name for a hallucinogenic/dream-like reality existing side by side with the "real" world. As a slipstream novel it contains a fuzzy set of epistemological and, most importantly, ontological ideas. It is in many aspects a science fiction novel, yet tends to quickly slip into inexplicable territories. Everything revolves around Vurt, yet we do not really receive a sufficient sci-fi explanation into its origins ${ }^{34}$ nor is that the focus of the novel. The more the plot advances, the

32 As if categories, such as New Weird, New Wave Fabulism, or Magic Realism are not obscure enough, Kelly and Kessel provide us with a new anthology of Post-Cyberpunk short stories.

33 For more on the metaphorical usage of fractal geometry in Vurt see Andrew Wenaus' Fractal Narrative, Paraspace, and Strange Loops:The Paradox of Escape in Jeff Noon's Vurt in Science Fiction Studies 38, no. 1 (March 2011): 155-174.

34 At the very beginning of the second novel set in the same universe Pollen (1995) we are given a partial explanation as to how humanity gained access to the realm called Vurt; however "... the actual origins of the Vurt and the method by which human beings travelled there (via 'dream feathers' which were placed into the mouth) will always be shrouded in mystery” (Noon 2001,3). 
more the differences between the real world and Vurt become fluid. In fact, one of the overarching themes of Vurt and its sequel Pollen seems to revolve around the concept of fluidity. The borders are breaking down between worlds and beings: "But the world is getting very fluid these days. Very fluid. Dangerously so. There are doors opening between the species" (Noon J. 2001, 106). There are at least five known "species" in this fuzzy Mancunian setting, ranging from literally undead to pure human, and with them scales of worth..$^{35}$ Concerning the species and the fluidity between them, there is an exposition ${ }^{36}$ about five modes of being (essentially, a taxonomy of species) - first level is that of purity/solidity, the final that of fluidity of unimaginable scale. Sex and cybernetic grafting are they key to opening up new modes and breaking the biological/ontological borders between them the existence of robodogmen or dogmanvurts is nothing out of the ordinary in this post-species ${ }^{37}$ world. The fluidity between different states of being/existence in Vurt goes beyond what science fiction would consider conventional, there is not only sex between dogs and men, but between men and entities originating in dreams and myths. ${ }^{38}$

The second theme I would like to touch upon revolves around the concept of chaos - "... attempting to understand the postmodern space, such as that exemplified by Vurt, through ordered and sequentially predictable Cartesian grids will be hermeneutically vain" (Wenaus, 163). To fathom the role of space in slipstream, and let us consider Vurt as an exemplary representative, one needs to not only move beyond the outer space mentality of the Golden Age science fiction, but also beyond cyberpunk - Vurt is not cyberspace ${ }^{39}$ and the zigzagging movement between worlds is not of electronic nature. This does not mean that we need to entirely forego cognitive estrangement and fully embrace cognitive dissonance. The aesthetic guidance for Jeff Noon was none other than chaos theory and quantum mechanics:

35 Science fiction generally likes to portray alternate societies with sociological underpinnings. In Vurt's case, we have a perfect example of slipstream social bricolage in which zombies, humanoid dogs, cyborgs, humans, and Vurt/dream-state entities function in an orderly/disorderly society, copulate, and even have offspring. And, as it is in the real world, there are conflicts between them with pure humans having the most privileges.

36 Expository mini-chapters are narrated by the peculiar Game Cat, a being who can inexplicably traverse between Vurt and the real world. Among his sly remarks we can find metafictional gems: "Chances are you, the reader, are a Second level being of some kind" (Noon 1994, 268).

37 Both Vurt and Pollen are brimming with hyper-miscegenation of species and cyborgs, yet there seems to be no room for a post-generic mindset.

38 This hyper-breeding between species is revealed in the second novel to have been caused by the concoction Fecundity 10. It can be argued that this is a science-fictional plot device par excellence, yet it is in this case basically a magic potion, somehow enabling copulation between corpses and living beings, between Vurt creatures and men.

Yet it is a consensual hallucination. 
What's happening in the twentieth century is that scientists have taken over the realms of the imagination ... And you see that again and again with chaos theory, complexity theory, relativity ... The universe became strange and was proven to be strange ... It's almost ... as though poetry had entered the universe ... and I think the artists and writers have been lagging behind. (qtd. in Wenaus 2011, 156)

Science fictional "sense of wonder" is thus rekindled in the latest science. Newtonian mechanics tell us the universe is structured, orderly, and predictable, chaos theory/nonlinear dynamics and the sub-atomic world, on the other hand, reverse the mindset. The ubiquitous fluidity of species and space open the narrative world of Vurt to chaotic transfigurations. Most importantly, the species and modes of being are given a new order out of disorder - new taxonomies on all levels of society emerge. Chaos theory provides a new/transvaluated meaning of order: "Literary theorists value chaos primarily because they are preoccupied with exposing the ideological underpinnings of traditional ideas of order. They like chaos because they see it as opposed to order. Chaos theorists, by contrast, value chaos as the engine that drives a system toward a more complex kind of order (Hayles 1990, 23)"; "The more chaotic a system is, the more information it produces. This perception is at the heart of transvaluation of chaos, for it enables chaos to be conceived as an inexhaustible ocean of information rather than as a void signifying absence" (8). In Vurt Noon aesthetically combines the disorder of Mancunian reality and the order inherent in postmodern space(s). Unlike the New Wave science fiction with its proclivity towards apocalypses and entropic disorders, ${ }^{40}$ the novel's stylistic usage of latest science shows us the new levels of complexity arising out of the detritus of postmodern trash. There is no need to entirely abandon the staple of cognitive estrangement in strange cases like Vurt. Behind the fractal narrative and chaotic plotline lies the aesthetic guidance of the latest philosophy of science rising out of the rigidity of the Euclidean universe, previous categories become a hindrance to the new perceptions and being in the postmodern world we consciously and unconsciously inhabit.

\section{CONCLUSION}

Science fiction in slipstream gains an unprecedented degree of complexity. Owing to genre miscegenation and latest paradigms of science, the dialectic between cognition and estrangement becomes a postmodern playground, in which the effect of "feeling strange" gains dominance over the rational resolutions, usually displayed in science fiction narratives. Cognitive dissonance becomes the guiding

40 See Colin Greenland's The Entropy Exhibition: Michael Moorcock and the British "New Wave" in Science Fiction. 
principle, contradictory views, beliefs, and perceptions are maintained in stories which may, at first, seem to possess the literary tropes of science fiction to resolve them, yet rapidly descend into territories science fiction has no maps for. The estrangement of the readers is specifically upheld by employing techniques, ranging from allegory, metafiction, pastiche to appropriation of multiple genre tropes from the fruitful domain of the fantastic literature. In slipstream the science fiction twists of quantum mechanics, nonlinear dynamics, and fractal geometry become a metaphor for the uncertainty and chaos of everyday life; rather than attempting to directly resolve the existential anguish, slipstream is there to assist us in portraying the strangeness and contradictoriness of the world, warts and all. The role of science fiction in all of this is, therefore, to provide new materials for the effectiveness of cognitive dissonance.

\section{REFERENCES}

Amerika, M. 1993. Altx Online Network. Avant-Pop Manifesto: Thread Baring Itself in Ten Quick Posts. http://www.altx.com/manifestos/avant.pop.manifesto. html (accessed 27 August 2012).

Brigg, P. 2002. The Span of Mainstream and Science Fiction: A Critical Study of a New Literary Genre. Jefferson, N. C.: McFarland.

Broderick, D. 2009. Unleashing the Strange: Twenty-First Century Science Fiction Literature. UK: Borgo Press.

Deleuze, G. and Guattari F. 2004. Anti-Oedipus: Capitalism and Schizophrenia. Translated by Robert Hurley, Mark Seem, and Helen R. Lane. London: Continuum.

Fenkl, H. I. 2007. Introduction to Interfictions: An Anthology of Interstitial Writing, ed. Delia S. and Theodora G, i-viii. Boston, MA: Interstitial Arts Foundation.

Frelik, P. 2009. Slipstream 101. Science Fiction Research Association. http://www. sfra.org/sf101slipstream (accessed 27 August 2012).

- 2011. Of Slipstream and Others: SF and Genre Boundary Discourses. In Science Fiction Studies 38, no.1 (March): 20-45.

Hayles, N. K. 1990. Chaos Bound: Orderly Disorder in Contemporary Literature and Science. Ithaca and London: Cornell University Press.

Kelly, J. P. 2009 . Foreword to $» 10^{16}$ to 1 «. In The Secret History of Science Fiction, ed. J P. Kelly and J. Kessel. San Francisco: Tachyon Publications.

-, and Kessel J. 2006. Introduction to Feeling Very Strange: The Slipstream Anthology, ed. J. P. Kelly and J. Kessel, vii-xv. San Francisco: Tachyon Publications.

McHale, Brian. 2003. Postmodernist Fiction. London and New York: Routledge.

Noon, J. 1994. Vurt. London: Pan Books.

-. 2001. Pollen. London: Pan Books. 
Rossi, U. 2002. From Dick to Lethem: The Dickian Legacy, Postmodernism, and Avant-Pop in Jonathan Lethem's Amnesia Moon. In Science Fiction Studies 29, no. 1 (March): 15-33.

Rucker, R. 1999. A Transrealist Manifesto. Rudy Rucker Portal. http://www. rudyrucker.com/pdf/transrealistmanifesto.pdf (accessed 27 August 2012).

Scholes, R. 1975. Structural Fabulation: An Essay on Fiction of the Future. Notre Dame \& London: University of Notre Dame Press.

St. Clair, J. 2011. Borrowed Time: Thomas Pynchon's Against the Day and the Victorian Fourth Dimension. In Science Fiction Studies 38, no. 1 (March): 46-66.

Sterling, Bruce. 2011. Slipstream 2. In Science Fiction Studies 38, no. 1 (March): 6-10.

Suvin, D. 1979. Metamorphoses of Science Fiction: On the Poetics and History of a Literary Genre. New Haven and London: Yale University Press.

Tatsumi, T. 2006. Full Metal Apache: Transactions Between Cyberpunk Japan and Avant-Pop America. Durham and London: Duke University Press.

Wenaus, A. 2011. Fractal Narrative, Paraspace, and Strange Loops: The Paradox of Escape in Jeff Noon's Vurt. In Science Fiction Studies 38, no.1 (March): 155-174.

Wolfe, Gary K. 2011. Evaporating Genres: Essays on Fantastic Literature. Middletown, CT: Wesleyan University Press.

-.2011. Symposium on Slipstream. In Fiction Studies 38, no. 1 (March): 11-19.

Janez Steble

Ljubljana, Slovenia johnsavant@gmail.com

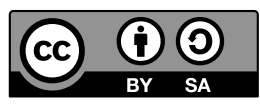

\section{Vloga znanstvene fantastike v fluidnosti slipstream književnosti}

Članek raziskuje kompleksno in kontradiktorno vlogo znanstvene fantastike v slipstreamu, tipu postmoderne nerealistične književnosti, pozicionirane med fantastičnimi žanri in mainstream književno prozo.

Ključne besede: slipstream, znanstvena fantastika, avant-pop, transrealizem, intersticijska proza, kognitivna disonanca, teorija kaosa 